\title{
3. Drug Use, Public Debate and Increasing Pressures for a Drug Policy Reform in Finland
}

Pekka Hakkarainen \& Heini Kainulainen

\section{Introduction}

In Finland, drug control was included in the criminal law for the first time at the beginning of the I970s, when the 1972 Narcotics Act was enacted. In the Parliament, the government bill for a new legislation created a fierce political debate on drug policy, especially on the issue of whether or not the use of drugs should be a punishable offence (Hakkarainen I999; Kainulainen 2009). In the government bill, the use of drugs was not proposed to constitute a criminal offence, but the Parliament Legal Affairs Committee recommended criminalization. The Commerce Committee supported the government's stand, whereas the Grand Committee after drawing lots - decided to support the recommendation of the Legal Affairs Committee.

Among the MPs, opinions regarding the criminalization of drug use largely divided along the axis between the political right and left (Hakkarainen I992). The left opposed criminalization, considering the drug problem to be a consequence of other social problems, and, rather than a criminal, saw a drug user as a sick person needing help and treatment. Supporters of criminalization stressed that the Parliament should show young people that drug use is not accepted by society. The criminalization of drugs was, then, seen as a preventive measure and it was believed that the risk of punishment would deter young people from experimenting

How to cite this book chapter:

Hakkarainen, Pekka and Kainulainen, Heini. Drug Use, Public Debate and Increasing Pressures for a Drug Policy Reform in Finland. In: Retreat or Entrenchment? Drug Policies in the Nordic Countries at a Crossroads, edited by Henrik Tham, 37-66. Stockholm: Stockholm University Press, $202 \mathrm{I}$. DOI: https://doi.org/Io.I6993/bbo.c. License: CC BY 4.०. 
with drugs. In the crucial vote in the Parliament, the government bill was defeated by $92-80$ votes, and the use of drugs was defined as a narcotics offence.

The time period from the I960s to the beginning of the I970s was characterized by active and relatively open political discussion about drug policy, but when the basic lines of policy were debated and drawn the criticism of the criminalization policy suddenly disappeared, even among the leftist parties. Instead of active discussion, political parties and politicians took a cautious and reluctant attitude towards any drug policy discussion other than that supporting current criminal control policy and the work of the police.

In the I980s, Nils Christie and Kettil Bruun, in their well-known book Den gode fiende. Narkokapolitik i Norden (I985), proposed radical changes in Sweden and Norway, but not in Finland. Due to a lower prevalence of drug use and control costs, changes in the Finnish drug policy were not necessary, they argued. Although there were a considerable number of people who used drugs in Finland at that time, it was generally assessed that the authorities had the situation under fairly good control, and the problems were regarded to be far less extensive than in Sweden, Norway or Denmark (e.g. Olsson et al. I993). However, viewing this from a long-term perspective, this was just wishful thinking.

In the beginning of the I990s, acceptance of drug use among the Finnish population was still very low and attitudes towards experimenting and use were unfavourable. In the media, images of drug users were entirely negative. Juha Partanen (2002) even described Finnish public attitudes towards drugs as 'narco-phobic'. In drug policy, Finland followed a restrictive line and the police intervened effectively not only in drug markets but also use and users (Kainulainen 2009; Kinnunen 2008). However, despite these circumstances a dramatic shift in the scale and nature of drug problems occurred later in the I990s, with thorough changes in the whole panorama of drug-related issues - the prevalence and patterns of use; the number of socially excluded, multiproblem drug users; social harms and health hazards associated with drug use, such as drug-related criminality, morbidity and fatal overdoses. 
In the context of alarming developments, the Ministry of Social Affairs and Health appointed a cross-governmental committee to prepare a national strategy for tackling drugs more effectively. In contrast with the language of public debate at the time, the committee's report, Drug Strategy 1997, broadened notions of the object of drug policy by describing the issue as a complex and contradictory phenomenon. In the report, drug use was defined not only as criminal behaviour, but also as a social issue and a threat to public health. The committee also distanced itself from the concept of a 'drug-free society', which was seen as an unrealistic goal for a reasonable and sustainable drug policy. Consequently, the committee report counterbalanced the prevalent crime policy approach by stressing pragmatic health policy measures aimed at prevention, treatment and harm reduction (such as substitution treatment and needle exchange programmes), social support and advisory services. In summary, the Drug Strategy I 997 created the new paradigm in the Finnish drug policy, the dual tracks model, where both harm reduction and criminal control approaches became well established and expansive (Hakkarainen, Tigerstedt $\&$ Tammi 2007; Tammi 2007).

Responsibility for the coordination of drug policy was given to the Ministry of Social Affairs and Health. A multi-ministerial group containing representatives from six key ministries in the areas of social affairs and health, justice, education, interior, finance and foreign affairs was founded for synchronizing activities. The strategy was followed and updated in governmental decisions in principle (Plan of Action) every four years. However, the Drug Strategy 1997 has never been critically evaluated or renewed as a whole. Furthermore, during the years, the documents of the plan of action have become more and more general and ritualistic in nature. One can ask, then, how well a strategy that is more than 20 years old can meet the challenges of today, when drug use and related harms have reached a new record level.

In this chapter, we will discuss the pressures for a drug policy reform in the context of increasing drug use and its consequences, which are seen in a growing number of drug deaths during the last decades in Finland. First, we will draw a picture of the expansive growth in drug use by presenting survey results on the prevalence 
of drug use and illustrating some key indicators of drug-related deaths. A conclusion to be drawn from this section is that the drug use situation in Finland has changed totally since the mid I980s when Christie and Bruun (I985) presented their analysis. The Drug Strategy 1997, with its dual-tracks policy, has not succeeded in stopping the unfortunate development of increasing drug use and related harms.

In the second part of the chapter, we move to different kinds of pressures towards a policy reform. We will start this section by showing survey results on how public opinion and attitudes towards drugs and drug policy have recently changed. Then we will review the demands and initiatives for a policy change claimed in different arenas of public discussion. The contributions to be scrutinized in this second part of the chapter involve contributions presented by the police, treatment experts, researchers, non-governmental organizations (NGOs), drug policy advocates and politicians. Data to be used in this part covers citizens' initiatives, blog posts, newspaper articles and other media coverage in the political debate.

At the end of this chapter, we will highlight the key findings of the paper. We will argue that urges for a retreat (Enzensberger I989; see Tham's Introduction in this volume) from the position adopted in the criminal law in the beginning of the I970s are growing. Consequently, decriminalization of all drug use should be thoroughly reconsidered. That would not mean legalization of drugs, nor that drug use would be acceptable or recommendable, but replacing punishment of drug users with an approach based, first of all, on social support and health care (Eastwood, Fox \& Rosmarin 20I6; Stevens et al. 20I9; Unlu, Tammi \& Hakkarainen 2020).

\section{Increased Prevalence of Drug Use}

In Finland, the development of the drug use issue has been monitored with the help of population-based drug surveys, which were conducted approximately every four years since I992, the latest survey being from 2018 (Karjalainen, Hakkarainen \& Salasuo 20I9; Karjalainen, Pekkanen \& Hakkarainen 2020). Representative random samples of the population aged between I 5 and 69 years old were drawn from the Finnish Population 
Information System. The institutionalized population, those without a permanent address, and the Åland Islands were excluded. In each survey, data were collected by self-administered, anonymous postal questionnaires, which the respondents received by mail and were asked to return in a prepaid envelope. Since 2010 , responding via the Internet has also been possible. The content of the questionnaire has concerned drug use and drug-related opinions and attitudes. The data was collected by Statistics Finland. The number of respondents has varied between 2 I 43 and 3485 . The response rate for the drug surveys decreased from $7 \mathrm{I} \%$ in 1992 to around $50 \%$ in the last three surveys (20I0, 20I4 and 20I8). However, a non-respondent study conducted in connection with the 20I4 survey showed that the prevalence of illicit drug use was very similar among non-respondents and respondents of the original survey (Karjalainen, Pekkanen \& Hakkarainen 2020). Figure 3 shows how the prevalence of any illicit drug use has developed between I 992 and 2018 .

As seen in Figure 3, the use of drugs has been constantly increasing. From 1992 to 2018 , the lifetime prevalence of any illicit drug use increased from $6 \%$ to $24 \%$, last year prevalence from I $\%$ to $8 \%$ and last month prevalence from almost nothing to $3 \%$. Hence, in 2018 , almost one quarter of the Finns surveyed had some experience of illicit drug use. As seen in the figure, the use of drugs has been more prevalent among men than among women. In 2018 , lifetime prevalence for men was $28 \%$ and for

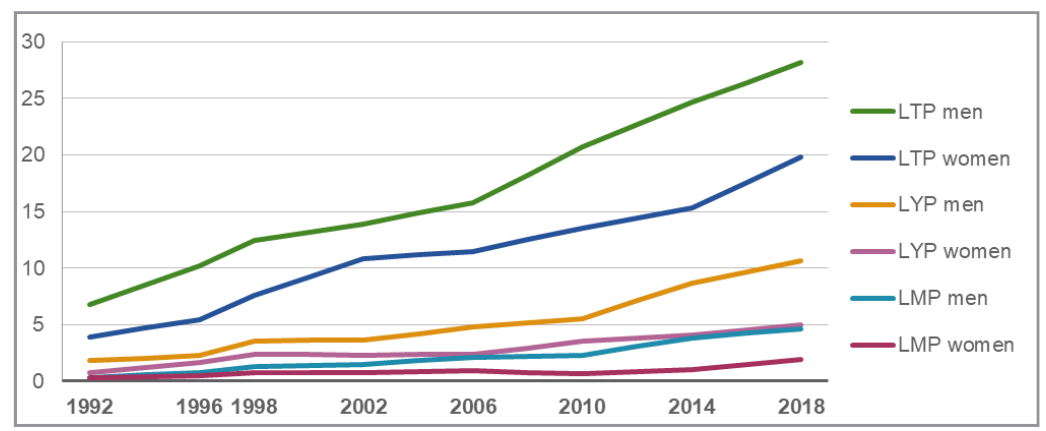

Figure 3. Lifetime prevalence (LTP), the last year prevalence (LYP) and the last month prevalence (LMP) of drug use according to gender between I992 and 2018 in Finland, \%.

Source: Karjalainen, Pekkanen \& Hakkarainen (2020). 
women $20 \%$, last year prevalence II $\%$ and $5 \%$, and last month prevalence $5 \%$ and $2 \%$ respectively.

The most popular choice of illicit drug is cannabis. Almost all who reported any drug use also reported cannabis use. The prevalence of the misuse of medicines (prescription drugs) was the second highest, followed then by amphetamines, ecstasy and cocaine, but all clearly at a lower level than cannabis. However, as shown in Figure 4, there are also upwards trends in the use of those drugs after 2010.

The spread of drug use varies largely across age groups. Lifetime prevalence of any illicit drug use according to gender and age is shown in Table Io. As can be seen, drug use is most prevalent among young adults aged $25-34$ years. Almost half $(45 \%)$ of them have tried illicit drugs at least once in their lifetime, one out of five reports use during the past year and one out of ten during the past month. In the Finnish context, these are high numbers. In the last 25 years, experimenting with drugs has turned from a relatively rare minority phenomenon to a wide-spread and rather normalized activity for young adults. Along with this development, in coming years we will have more experienced and 'drug wise' people in older age groups.

In the I990s and 2000 it was usual that the highest prevalence of drug use was found in the youngest age group, especially in the last year and last month prevalence categories. Due to this, it has been typical to describe drug use as a youth phenomenon.

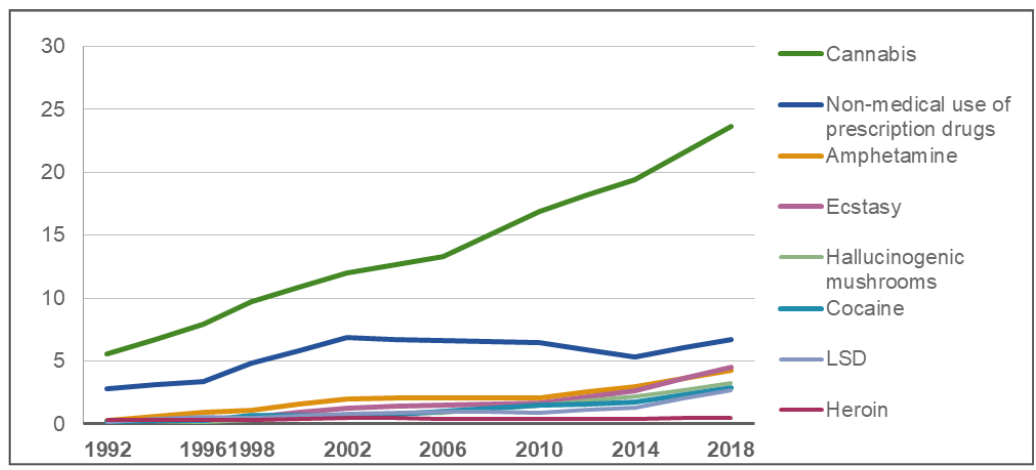

Figure 4. Lifetime prevalence of the use of different drugs between 1992 and 2018 in Finland, \%.

Source: Karjalainen, Pekkanen \& Hakkarainen (2020). 
Table 10. Lifetime, the last year and the last month prevalence of any illicit drug use according to gender and age groups in Finland, I992-201 $8, \%$.

\begin{tabular}{|c|c|c|c|c|c|c|c|c|}
\hline $\begin{array}{l}\text { Lifetime } \\
\text { prevalence }\end{array}$ & $\begin{array}{l}1992 \\
\%\end{array}$ & $\begin{array}{l}1996 \\
\%\end{array}$ & $\begin{array}{l}\text { I998 } \\
\%\end{array}$ & $\begin{array}{c}2002 \\
\%\end{array}$ & $\begin{array}{c}2006 \\
\%\end{array}$ & $\begin{array}{c}2010 \\
\%\end{array}$ & $\begin{array}{c}2014 \\
\%\end{array}$ & $\begin{array}{c}2018 \\
\%\end{array}$ \\
\hline All & 6 & 8 & IO & I 2 & I 4 & I7 & 20 & 24 \\
\hline \multicolumn{9}{|l|}{ Gender } \\
\hline Males & 7 & I I & I 2 & I 4 & I 6 & $2 I$ & 25 & 28 \\
\hline Females & 4 & 6 & 8 & I I & I 2 & I4 & I 5 & 20 \\
\hline \multicolumn{9}{|l|}{ Age } \\
\hline I $5-24$ & I 2 & I 5 & I9 & 26 & I9 & $2 I$ & 24 & 26 \\
\hline $25-34$ & I I & I 6 & I9 & 20 & 26 & 37 & 39 & 45 \\
\hline $35-44$ & 6 & 9 & 8 & I I & I6 & 23 & 26 & 32 \\
\hline $45-69$ & I & 2 & 3 & 5 & 6 & 6 & IO & $\mathrm{I} 2$ \\
\hline $\begin{array}{l}\text { The last year } \\
\text { prevalence }\end{array}$ & $\begin{array}{c}1992 \\
\% \\
\end{array}$ & $\begin{array}{c}1996 \\
\% \\
\end{array}$ & $\begin{array}{c}1998 \\
\% \\
\end{array}$ & $\begin{array}{c}2002 \\
\% \\
\end{array}$ & $\begin{array}{c}2006 \\
\% \\
\end{array}$ & $\begin{array}{c}2010 \\
\% \\
\end{array}$ & $\begin{array}{c}20 I 4 \\
\% \\
\end{array}$ & $\begin{array}{c}2018 \\
\%\end{array}$ \\
\hline All & I & 2 & 3 & 3 & 4 & 5 & 6 & 8 \\
\hline \multicolumn{9}{|l|}{ Gender } \\
\hline Males & 2 & 3 & 4 & 4 & 5 & 6 & 9 & I I \\
\hline Females & I & 2 & 2 & 2 & 2 & 3 & 4 & 5 \\
\hline \multicolumn{9}{|l|}{ Age } \\
\hline I $5-24$ & 6 & 9 & I 2 & I 2 & 9 & I 3 & I 6 & I 5 \\
\hline $25-34$ & 2 & 3 & 3 & 4 & 8 & I I & I3 & I 8 \\
\hline $35-44$ & I & I & I & I & 2 & 2 & 5 & 7 \\
\hline $45-69$ & 0 & 0 & 0 & 0 & I & $\circ$ & I & I \\
\hline $\begin{array}{l}\text { The last month } \\
\text { prevalence }\end{array}$ & $\begin{array}{c}1992 \\
\% \\
\end{array}$ & $\begin{array}{c}\text { I996 } \\
\%\end{array}$ & $\begin{array}{c}\text { I998 } \\
\% \\
\end{array}$ & $\begin{array}{c}2002 \\
\% \\
\end{array}$ & $\begin{array}{c}2006 \\
\% \\
\end{array}$ & $\begin{array}{c}2010 \\
\% \\
\end{array}$ & $\begin{array}{c}20 I 4 \\
\% \\
\end{array}$ & $\begin{array}{c}2018 \\
\% \\
\end{array}$ \\
\hline All & ० & I & I & I & I & I & 2 & 3 \\
\hline \multicolumn{9}{|l|}{ Gender } \\
\hline Males & ० & I & I & 2 & 2 & 2 & 4 & 5 \\
\hline Females & o & I & I & I & I & I & I & 2 \\
\hline \multicolumn{9}{|l|}{ Age } \\
\hline I 5-24 & I & 3 & 3 & 4 & 5 & 3 & 6 & 6 \\
\hline $25-34$ & I & I & 2 & 2 & 3 & 4 & 5 & 7 \\
\hline $35-44$ & ० & o & ० & O & I & I & 2 & 3 \\
\hline $45-69$ & 0 & 0 & 0 & ○ & $\circ$ & $\circ$ & I & I \\
\hline
\end{tabular}

Source: Karjalainen, Hakkarainen \& Salasuo (2019). 
However, in the last Io years the development of drug use seems to have turned this pattern upside down. For example, a study comparing the spread of drug use among minors and young people aged between 18 and 25 concluded that the increasing trend of drug use was prevalent only in the older part of this age group, while the development among minors remained stable (Karjalainen, Hakkarainen \& Raitasalo 20I9). Figure 5 shows the trend in the prevalence of cannabis use in the last year in I 5-24-year-old and 25-34-year-old males and females.

In 2018 there were 3.8 million inhabitants between I 5 and 69 years old in Finland. Based on the survey results then, it can be estimated that close to I million Finns have tried illicit drugs at least once in their lifetime. However, it is important to note that most of them are not active users, rather, the question is about past experiences in some earlier phase in their life. The number of those having used in the past year is around 300,000. Every month more than I00,000 Finns use illicit drugs. The vast majority of the people included in these figures are just experimental or occasional users, typically smoking cannabis a couple of times in a year when cannabis happens to be available. The number of those who smoked cannabis at least once a week was estimated at around 45,000, the number of daily users being roughly I 2,000.

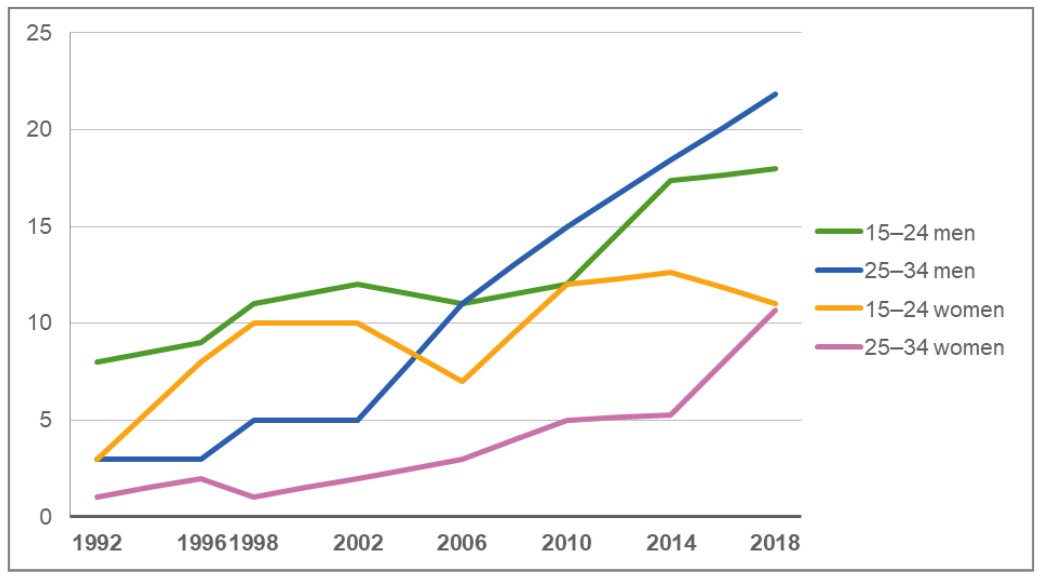

Figure 5. Last year prevalence of cannabis use between 1992 and 2018 in age groups below 35 years, according to gender, $\%$. Source: Karjalainen, Pekkanen \& Hakkarainen (2020). 
Regarding the use of hard drugs, a register-based study estimated the number of problematic users of amphetamines and/or opioids in 2012 to be $18,000-30,000$ (Ollgren et al. 20I4). Five years later, in 20I7, the estimate was 3I,IOO-44,300 (Rönkä et al. 2020). Findings of waste water studies conducted in Finnish cities between 2OI 2 and 20I 8 support assessments of the register-based study by showing a continuous increase in the samples of amphetamines, methamphetamines and cocaine found (Gunnar, Kankaanpää \& Kuoppasalmi 20ı9; Kankaanpää et al. 20ı6).

\section{Growing Number of Drug Deaths}

Following the Drug Strategy 1997, opioid substitution treatment (OST) was approved in Finland in the late I990s and early 2000 s (Selin et al. 20I3). Since then, OST has become an integrated part of Finnish drug policy. In 2015 , around 3300 people received OST in Finland (EMCDDA 20I9). The first Needle Exchange Program (NEP) was opened in 1997 in Helsinki and, despite a hard public controversy in the beginning, the practice spread rapidly (Tammi 2007). Today, the Communicable Disease Decree prescribes municipalities to provide health counselling services for injecting drug users, including the exchange of injecting equipment. In 20I 7, 5.8 million syringes were given out. The purposeful adaptation of NEP was a success story, since it has caused the number of HIV infection diagnoses to fall or remain at a low level since the beginning of the 2000s (Arponen et al. 2008).

While Finland has invested in OST, NEP and other low-threshold services, the number of drug-related deaths has increased markedly. From 2015 to 2017 the number of registered drug-induced deaths increased from I 66 to 200 . Hence, in 2017 , there were 53 drug-induced deaths per million inhabitants aged I 5-64 years in Finland, which was clearly higher than the European average (22) but lower than the neighbouring countries of Estonia (130), Sweden (92) and Norway (75) (EMCDDA 2019).

The latest information reveals that this unfavourable trend has continued, with the number of drug-induced deaths jumping to 26I in 2018 (Yearbook of Alcohol and Drug Statistics 2019). An increase in mortality rate was greatest in the 20-29 year age group (OSF 2019). Figure 6 shows upwards trends in the number of 


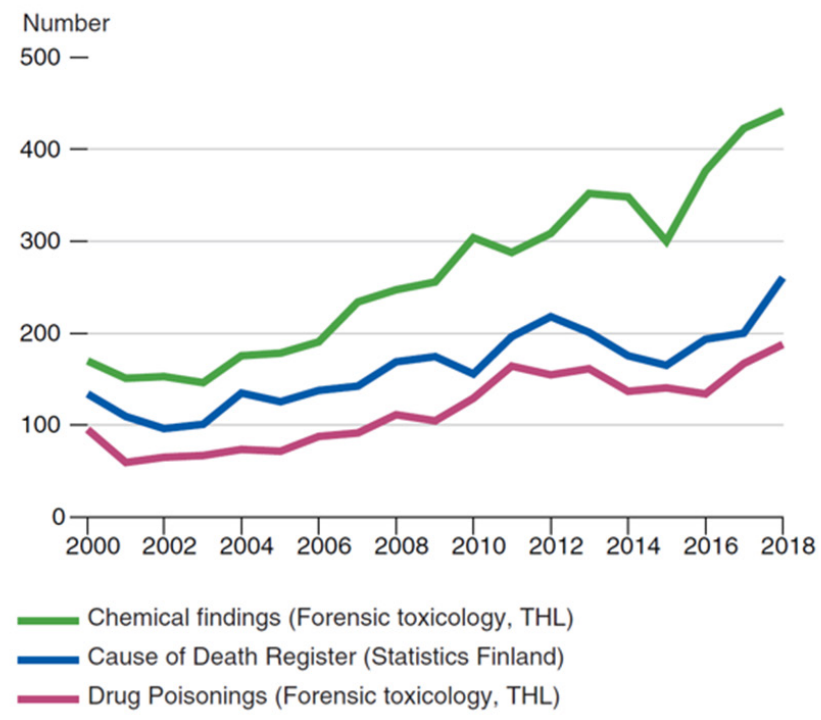

Sources: Forensic toxicology, THL; Causes of death. OSF. Statistics Finland.

Figure 6. Drug-related deaths according to drug poisonings (overdose deaths), cause of death (drug-induced deaths) and chemical findings in forensic autopsies, 2000-20I 8.

Source: Yearbook of Alcohol and Drug Statistics (2019).

cases with confirmed findings of drugs in forensic autopsies, cases whereby drugs are given as the cause of death on the death register (drug-induced deaths) and cases of drug poisonings. Druginduced deaths are deaths that can be attributed directly to the use of illicit drugs. The category of chemical findings in forensic autopsies provides an even higher death rate, while limiting just to poisonings and overdoses gives a somewhat lower rate. All of them, however, show an upward trend.

Most of the deaths are caused by simultaneous polydrug use (Salasuo et al. 2009). Toxicological data indicate that buprenorphine, usually in combination with alcohol or benzodiazepines, was involved in the majority of deaths. What is typical to the Finnish drug scene is that buprenorphine is the most popular opioid in use, while the use of heroin is almost non-existant. Furthermore, high mortality rate among drug users is associated with marginalization and social disadvantages like lower education, long- or 
short-term unemployment, early retirement, divorce and inadequate housing conditions (Rönkä 20I8). Among men under 40 years old, drugs are now the most common cause of death.

In sum, the prevalence of drug use and related harms are not at an insignificant level anymore, as estimated some 30 years ago (Christie \& Bruun 1985; Narkotikasituationen i Norden I993). In concert with increased drug use, problem drug use and different kinds of drug-related harms, the societal costs of drug problems have also expanded. According to the Yearbook of Alcohol and Drug Statistics (2019), the direct costs of harms caused by drug use totalled $€ 299$. I-369.5 million in 20I6. The increase from the total costs in $20 \mathrm{I} 4$ was $10.2 \%$. Taking account of the increase in drug use and related harms after 2016, we can state that the costs today are much higher. If taking indirect costs (e.g. a loss of productivity and working hours) into consideration, the total costs of drug problems might come up close to a billion.

\section{Pressures for a Change}

Public opinion and attitudes towards drugs and drug policy

Public opinion and attitudes towards drugs have eased and liberalized substantially during the last years. This holds especially true for attitudes towards cannabis. In I996, no more than $26 \%$ of the Finnish population aged I 5-69 years old was of the opinion that experimenting with cannabis once or twice would be risk-free or include only a slight risk. In 201 8 , a similar belief was shared by a good half of the population $(52 \%)$. At the same time, acceptance of regular use of cannabis has increased, but attitudes towards the risks of experimenting with heroin remain very critical. This indicates that a growing amount of people in Finland make a clear distinction between cannabis and hard drugs. Among the young adults, almost $75 \%$ see the risks of experimenting with cannabis as insignificant, with one quarter of them $(26 \%)$ regarding the risks of regular cannabis use in the same way (Karjalainen, Pekkanen \& Hakkarainen 2020).

Relaxed views on cannabis are reflected also in the opinions about criminal policy. In $2018,42 \%$ of Finns thought that the use of cannabis should not be punished. In the beginning of the I990s, 


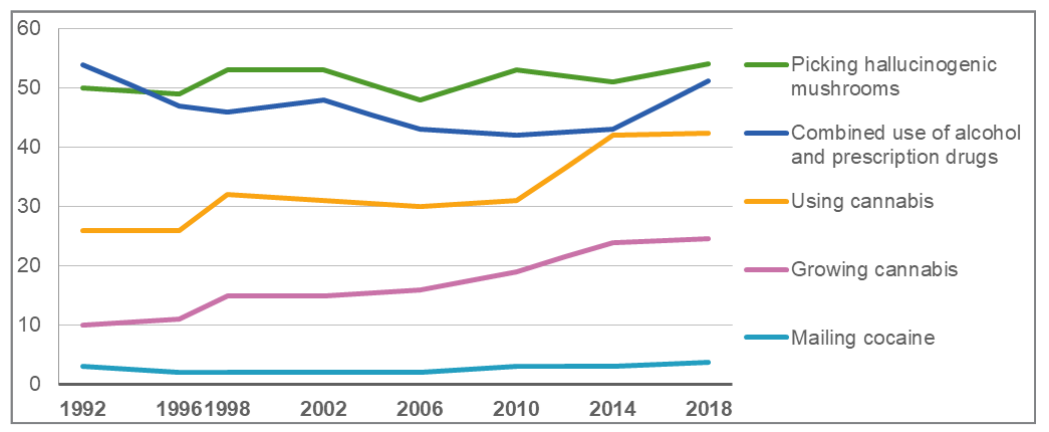

Figure 7. Attitudes towards punishment for various drug-related behaviours: no punishment, I992-201 8 , \%.

Source: Karjalainen, Hakkarainen \& Salasuo (2019).

this outlook was shared by one quarter of people. In Figure 7 , attitudes towards the punishment of cannabis use are shown in relation to some other forms of drug behaviour.

Among the people of Finland, picking mushrooms for the pot is a popular hobby connected to the right of common access to woods and forests. Perhaps due to that folk tradition, picking hallucinogenic mushrooms was not seen as a punishable action by the majority. Conversely, opinion regarding mailing cocaine from abroad to Finland was seen almost unanimously as a punishable act. Actually, in Figure 7, only attitudes towards using or growing cannabis show a trend of relaxation.

When respondents were asked whether or not they agreed if drug use of any kind should be punished, only $20 \%$ of them were in favour of stopping punishment. That was more than in 2002 ( $14 \%)$, when it was previously asked. These results reinforce the fact that the Finnish people are making a distinction between cannabis and other drugs. Furthermore, results indicate that it seems to be more difficult to show tolerance towards all drug users than towards cannabis users. Indeed, it might be more challenging for the general public to feel and show similar understanding towards problematic polydrug users who are visible in public places than towards cannabis smokers who mostly represent ordinary young people (Hakkarainen \& Karjalainen 20I7; Savonen et al. 2018). Due to the special nature of the cannabis issue, Figure 8 focuses on public opinions regarding cannabis legalization. 


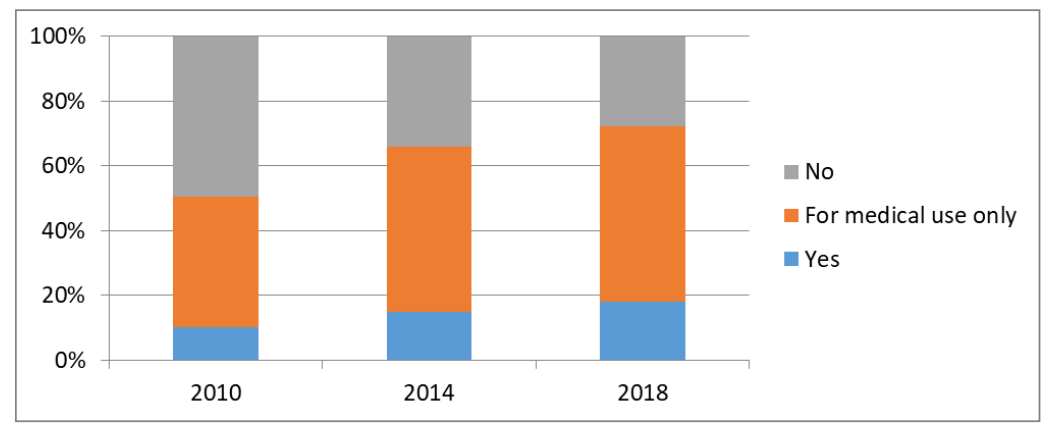

Figure 8. Opinions on whether cannabis should be legally available, 20I0-20I 8 .

Source: Karjalainen, Pekkanen \& Hakkarainen (2020).

While attitudes towards cannabis have relaxed remarkably, support for the legalization of cannabis has remained at a moderate level among the general public. Between I 998 and 2010, endorsement for legalization stayed very stable, at Io-I I \%. However, during the last eight years approval has grown to $18 \%$. At the same time, the share of people who are in favour of legalization for medical use only has grown from 40 to $54 \%$. Hence, acceptance of medical cannabis covers $72 \%$ of the general public altogether. Consequently, the proportion of people who are against any forms of legal access has dropped from 49 to $28 \%$ - less than one third of the Finnish population (Karjalainen, Pekkanen \& Hakkarainen 2020).

In summary, from studying these figures, it is reasonable to conclude that the public opinion on policy issues did not start to change until recently. During the last eight years, however, policy attitudes regarding cannabis have relaxed quite rapidly. This has been most obvious among young people. Around one quarter of young adults in Finland think that the use of any drug should not be punishable, and a narrow majority of them would remove punishment from the use of cannabis.

\section{Citizens' initiative}

A change in the social position of cannabis, which is reflected in public attitudes, can also be seen in increased political activism with relation to drugs. The most important indication of the public 
emergence of cannabis advocacy is a citizens' initiative calling for the decriminalization of cannabis use, which had received 59,609 certified signatures by the I November 2019, and then succeeded to qualify to the Parliament proceedings. There have also been some citizens' initiatives on cannabis issues in previous years, but the number of supporting signatures has remained below 50,000 - the number demanded to advance to the Parliamentary proceedings. Hence, this is the first time the Finnish Parliament will deal with cannabis policy based on an initiative prepared by cannabis activists and supported by a relatively large number of citizens. Because of the Covid-I9 pandemic, parliamentary readings of the initiative did not start until late autumn 2020 , and the process will continue in the Committee of Law in $202 \mathrm{I}$.

In addition to the use of cannabis, the initiative proposes decriminalization of possession of small amounts of cannabis for own use and growing of four cannabis plants for personal use (see also Eastwood 2020). In the initiative, it is argued that decriminalization of cannabis is needed because current drug policy has not succeeded in reducing the number of drug-related harms. It is also said that control of cannabis users randomly focuses only on a small group of users, wastes police resources and interferes with the everyday life of users. Furthermore, it is stated that removing cannabis from under legal control would diminish the growth of organized crime. Home grown cannabis plants for own use without legal sanctions is seen to provide safer and better quality cannabis than buying it from illicit markets.

\section{THL blog posts}

Another, and earlier, impulse for a public discussion on drug policy was published in February 201 8, when in a blog post of the Finnish Institute for Health and Welfare (THL) researchers proposed that Finland should decriminalize all drug use (Hakkarainen \& Tammi 20I8). With reference to the statements of international organizations, such as the World Health Organization (WHO) and the Global Commission on Drug Policy, it was stated that drug use should instead be tackled by means of social and health care, rather than criminal law and punishment (see also Das \& Horton 2019). The blog also made clear that decriminalization should apply to 
all drugs. The legalization of cannabis and its trade is, however, not timely in Finland, researchers stated in the blog.

One of the main arguments given in the blog post was that it would prevent harm caused by criminal control in the lives and careers of young people. As known, occasional use of cannabis in a circle of friends is a wider-spread practice in some age groups. Since almost a half $(45 \%)$ of young adults aged $25-34$ in Finland have tried cannabis at least once in their lifetime, it is not reasonable that the current legislation defines and treats them all as criminals. Another argument was that it would reduce the stigma of drug use and support problem drug users to attend treatment. When a person who uses drugs does not have to fear punishment or other criminal sanctions, it is much easier for him or her to attend social and health services for help. Also, talking about drug use in various services, such as health services at schools, occupational healthcare and general healthcare services, would become more natural for both parties if drug use was no longer labelled as a criminal behaviour.

In general, the blog post argued that the criminal sanctions work poorly in the prevention of the use of drugs, and the related harms, and they are also ill suited to the values of today's society or to public health thinking. Instead of being punishable, new means and procedures are needed to prevent drug use and reduce harm. Lessons can be drawn, for example, from how smoking has been reduced without criminalization. Furthermore, the authors referred to positive experiences of decriminalization in Portugal in 200I (Greenwald 2009; Hughes \& Stevens 2010), and the plans to apply that model by our neighbouring country, Norway (NOU 2019).

Later in June another blog post was published where authors reviewed the discussion and proposed that a reform of national drug strategy should be taken in the agenda of the next government (Eskola et al. 20I8). This blog post also paid attention to a relatively high number of drug-related deaths in Finland. In general, authors argued that there is evidence showing that strictness of drug policy seems to have a stronger impact on how drug users are treated rather than on the prevalence of drug use (e.g. Reuband I998), and that individuals in countries with more 
liberal approaches to drug use are showing a greater confidence in engaging with services and in seeking help than individuals living in countries with harsher approaches to drug use (Benfer et al. 20I8). This blog post was signed by Juhani Eskola, the general director of THL, expressing an official stance of the institute.

\section{Media and increased public discussion}

The February 20 I 8 blog post immediately created a lively discussion. It was downloaded over ten thousand times in a couple of weeks and it was widely reported in newspapers, on radio and on television. It evidently was a kind of surprise for the public that this kind of proposal was delivered from the institute, which is a respected national body and the Finnish government's leading health and welfare agency working under the Ministry of Social Affairs and Health. In social media, THL was given credits due to the radical opening of the discussion and it was also stated that the blog justified the criticism of current drug policy and made it easier for other people to express alternative views too.

The blog was reviewed and commented on in editorials of six newspapers. For example, Helsingin Sanomat, the biggest and most influential newspaper in Finland, provided its editorial with the headline, 'Required contribution'. ${ }^{2}$ The newspaper described the content of the blog but didn't take a stance for or against decriminalization. Editorials of five other newspapers also saw the blog as a welcome input for discussion, but expressed their reserved attitude by emphasizing that drugs are dangerous ${ }^{3}$ or that decriminalization would increase liberal attitudes towards drugs, especially among the youth. ${ }^{4}$ Furthermore, Savon Sanomat, Kaleva and Huvudstadsbladet stated that in Finland it would be

2 Tarpeellinen pubeenvuoro, Helsingin Sanomat I 5.2.20 I 8 (editorial).

3 Huumeet eivät ole harmittomia - rangaistuksista luopuminen lisää käyttöä, Ilta-Sanomat I6.2.20I 8 (editorial) and Harmitonta huumetta ei ole, Länsi-Suomi 22.2.20I 8 (editorial).

4 Huumeiden salliminen synnyttäisi unsia ongelmia, Savon Sanomat I7.2.20I 8 (editorial), Hummeita vastaan unsin tavoin, Kaleva 17.2.20I 8 (editorial) and Straff eller vård - är avkriminasering en lösning?, Hufvudstadsbladet I3.5.201 8 (editorial). 
reasonable to wait and see what happens in Norway if drug use is decriminalized there.

In the following weeks, innumerable newspaper articles were published and TV and radio programmes broadcast. In addition to the authors, the media interviewed different kinds of experts in drug issues. Academic researchers and experts specialized in addiction problems in health and social care were mostly supportive of arguments for decriminalization, while police authorities expressed a lot of reservations and were mostly against any liberalization of drug policy or control of drug users. For example, academic experts of criminal law stated that criminal penalties are unnecessarily harsh and ineffective measures in the control of drug use, and also violate the usual practice of the Finnish judicial system. ${ }^{5}$ Social workers in drug treatment were accompanying the experts of criminal law by emphasizing how stigmatization of drug users creates shame and delays them in seeking help and treatment. ${ }^{6}$ Police authorities, on the other hand, stressed that due to general deterrence it is important to intervene in drug use, especially among young people. ${ }^{7}$ In general, the police tend to argue that control of use and users is useful for them in uncovering and investigating more serious drug crimes, such as drug dealing and smuggling. Hence, contrary to treatment experts, the police were clearly not ready for a retreat in criminalization of drug use, not even if it also emphasized the importance of drug treatment.

In November 2019, when the citizens' cannabis initiative qualified to be submitted to Parliament for consideration, public debate on drug policy increased again. Actually, the whole process around the citizens' initiative has been accompanied by lively public discussion in newspapers, radio, television and social me-

5 Pitääkö huumeista rangaista vai ei?, Helsingin Sanomat I 5.2.2018, 'Rikoslakia huudettu apuun ähkyyn asti' - professori poistaisi rikoslaista liikennerikkomuksia ja huumeiden käytön, Rikos-Uutiset-MTV.fi I7.3.20I 8 and Kriminaalipolitiikka vaatii visiota, (rikosoikeuden prosessori Kimmo Nuotion syntymäpäivähaastattelu), Helsingin Sanomat I8.4.20I9.

${ }^{6}$ Pitääkö huumeista rangaista vai ei?, Helsingin Sanomat I 5.2.20I 8.

7 Huumausaineiden käyttörikoksista suureen osaan liittyy muita, vakavampia rikoksia, Savon Sanomat 6.5.2018. 
dia. Since the case is not yet closed, the initiative will also fuel policy discussion in the long term.

\section{Mobilization of NGOs}

Proposals for the decriminalization of drug use and re-evaluation of the national drug strategy got support from key NGOs working in the field of drug problems. These organizations were A-Clinic Foundation, ${ }^{8}$ Sininauhaliitto, ${ }^{9}$ EHYT ry, ${ }^{10}$ Humaania päihdepolitiikkaa-yhdistys (HPP) $\mathrm{ry}^{\mathrm{II}}$ and Irti Huumeista ry. ${ }^{\mathrm{I2}}$ Some of them didn't want to commit to decriminalization yet, but they all agreed that it would be time to update and re-evaluate the national drug strategy. For example, EHYT ry. included a claim for a new national drug strategy in its four objectives suggested for the new government after the Parliamentary elections in spring 2019. Sininauhaliitto visited all parliamentary parties while lobbying for a new drug strategy, and the head of the organization was an advocate for the decriminalization policy. HPP was extremely active in social media, and they also arranged a successful seminar 'Drug Policy - Now!', with foreign speakers from Portugal, Norway and the UK. The seminar also included a panel discussion with Finnish politicians from all Parliamentary parties and the Pirate-party.

${ }^{8}$ The A-Clinic Foundation is a non-governmental and non-profit organization and service provider that was founded in I955. The central office is involved in national and international activities in the fields of prevention, information, development and training (see more https://a-klinikka saatio.fi/en).

9 Sininauhaliitto is a member of the The International Federation of the Blue Cross, which is a politically and denominationally independent Christian organization consisting of about 40 member organizations engaged in the prevention, treatment and after-care of problems related to alcohol and other drugs (see more https://www.sininauhaliitto.fi/).

ro EHYT Finnish Association for Substance Abuse Prevention is an NGO working in substance abuse prevention with a broad and collaborative approach. EHYT's membership comprises around one hundred national, regional and local organizations (see more https://ehyt.fi/en/).

I HPP, Society for Humanistic Drug Policy is a member of the International Drug Policy Consortium (IDPC) and is promoting a drug policy reform in Finland (see more http://hppry.fi).

${ }^{\text {I2 }}$ Irti Huumeista ry is a voluntary NGO founded 35 years ago with the aim of preventing drug use and supporting parents of drug users (see more https://irtihuumeista.fi/). 
In a small country with good cooperation between government and civil society like Finland, NGOs have had good opportunities to influence official politics, to be included in working groups and in the drafting and implementation of the national action plans. Consequently, mobilization of NGOs dealing with drug issues had a very important role in furthering discussion on drug policy at different levels of civil society. In addition to their own initiatives, representatives of the above-mentioned organizations were often interviewed as experts or used as news sources in different forums of mass media.

\section{Politicians}

When the first round of the debate got started by the THL blog post, relevant ministers, the Minister of Justice and the Minister of the Interior were interviewed about their standpoints by the media. They were all reserved and not in favour of decriminalization. The Minister of Social Affairs and Health, representing a party in political Center, was afraid that decriminalization would lead to an increase in drug use. ${ }^{13}$ The Minister of Justice, representing a party in political Right, accompanied this by saying that drug use should not be made easier in any way, while his party mate, the Minister of the Interior, stated that the police should focus on drug markets and supply. ${ }^{\mathrm{I}}$

However, on the second round of the debate, the setting had changed because of the parliamentary elections and a new government appointed in spring 20I9. The new government, consisting of Social Democratic Party (SDP), Centre Party, Green League, Left Alliance and Swedish People's Party (RKP), have shown interest in updating at least some drug policy. In the government programme it undertakes an updated and joint strategy for alcohol, drugs, tobacco and gambling, as well as a decision in principle for drug treatment and harm reduction (Osallistava ja osaava Suomi 20I9). In the public debate, three ministers of the new government said they supported decriminalization of all drug use,

${ }^{13}$ Ministeri Saarikko THL:n hummekananotosta: Suomessa rangaistusten poisto voisi lisätä käyttöä, Ilta-Sanomat I 5.2.2018.

${ }^{14}$ THL:n johto toivoo keskustelua huumeiden käytön laillistamisesta kokoomusministerit eri linjoilla, Talouselämä I 5.2.20I 8 . 
while the Prime Minister and the Minister of Justice took a reserved view by saying that this government will not move forward in that direction. A statement supporting the decriminalization of all drug use presented by the Minister of Interior and the party leader of the Green League got special attention due to the fact that she is also a responsible minister of the police. ${ }^{15}$

There were also opposite views between political parties. ${ }^{16}$ Those most strongly against decriminalization seemed to be the Christian-democratic Party, right-wing populist Finns Party and right-wing liberal-conservative National Coalition Party, who are all in opposition in the Parliament at the moment. Social democrats have also been reluctant with regards to decriminalization, but they have stressed the importance of developing better treatment and harm reduction measures. The Green League has made a decision in their political programme that they support decriminalization, while the Left Alliance Party has defined it as a question of consciousness that leaves freedom to choose to individual MPs. The Minister of Justice and the party leader from RKP has opposed decriminalization, but the official mouthpiece of the party, Huvudstadsbladet, has taken a stance supporting decriminalization in an editorial. ${ }^{17}$

Furthermore, drug policy reform has been debated in the youth organizations of the parties and some of them (Green League, Left Alliance and RKP) have taken a supportive stance towards decriminalization. ${ }^{18}$ Also, some individual members of youth

${ }_{15}$ Ohisalo: Vibreät kannattaa huumeiden käytön rangaistavuudesta luopumista, Yle.fi 30.10.2019.

${ }^{16}$ Katso puolueiden kannat: Vibreät haluaa, ettei huumeiden käytöstä rangaistaisi - Li Andersson ehkä -linjalla, Iltalehti 27.2.2018. Vibreä aalto etenee maailmalla, mutta milloin kannabis laillistetaan Suomessa? Näin vastaavat puolueet, Yle I 8.3.20 I 8, https://yle.fi/uutiset/3-I0663 I 5 I, and Haavisto ja Andersson luopuisivat huumeiden käytön rangaistavuudesta - Halla-aho eri linjoilla: Huumeet aiheuttavat selkeitä ongelmia ja lisäävät rikollisuutta, Suomen Uutiset 8.4.2019.

${ }^{17}$ Cannbisdiskussionen gick upp $i$ rök, Huvudstadsbaledet 26.II.20I9 (editorial).

I8 Fler ungdomsförbund för avkriminalisering: 'Kriget mot drogerna har inte fungerat', Yle 2.5.2018, https://svenska.yle.fi/artikel/2018/05/02 /fler-ungdomsforbund-for-avkriminalisering-kriget-mot-drogerna-har-in te-fungerat. 
organizations of other political parties (Centre Party, National Coalition Party and SDP) have publicly defended reforming views. This indicates that younger generations, who see drug issues differently from older ones, are pushing changes in their parties.

\section{Retreat: A Redistribution of Labour between Social and Health Care and Criminal Control Policy}

At the time of writing this chapter, solutions are still open. Preparation of the national strategy for alcohol, drugs and addictions (including tobacco and gambling issues), and the decision in principle on drug treatment and harm reduction have been going on for a while under the Ministry of Social Affair and Health, but have not yet been launched. Debate in the Parliament about the citizens' initiative calling for the decriminalization of cannabis use has just started. In the first public hearing arranged by the Committee of Law in February 202 I, THL proposed decriminalization of all drug use and got support from a professor in criminal law at the University of Helsinki, while a representative of the police was against any decriminalization. Whatever the coming resolutions will be, it is evident that the debate on drug policy will be continued.

When studying the central trends of the development of the drug situation in Finland in the past two decades it becomes apparent that, regardless of the strict criminal policy and the dual-tracks reform done in the late I990s, drug use and related harms have been continuously increasing. In fact, a growing number of young people experimenting and using drugs makes them the targets of police control and vulnerable in terms of exclusion from schooling and the labour market. As reported by drug users, the criminal control has a stigmatizing effect that is difficult to escape (Heinonen I989; Kainulainen, Savonen \& Rönkä 20I7; Kontula, Aleskerov \& Neuvonen 2020). Having a recorded history of drug use often has a negative impact on a person's life, and its disclosure can be a barrier to access to education or employment. A growing number of experimenters and occasional users may also lead to an increasing number of problematic drug users in need of support and services. However, the criminalization of drug use clearly makes it difficult to seek help, 
support and treatment. Avoiding or delaying seeking help exposes individuals to fatal overdoses and other detrimental consequences. Altogether, this unfavourable development gives us a reason to ask whether the Finnish society should seriously consider a retreat in the drug policy field. As Enzensberger (I989) states, although a retreat might include violating earlier principles and moralities, it might bring along solutions that are more important and healthier for the society than stubborn refrain in old models and holding back from doing something.

How probable would this kind of development be in Finland? Are we ready to retreat from old principles and conceptions of drug policy and try to find new directions? We think that there are some signs and processes going on that call for chance.

First, in the creation of novel drug policy lines a very basic aim was to protect youth, especially minors, and keep them off of drugs. Today, however, the core of drug use lies in the young adult age group - a more independent, resourceful and self-assertive group of people to be controlled than teenagers. They want to judge and decide their personal habits and pleasures by themselves, and many of them see current control policy as unjust or irrelevant. Defining half of the age cohort as criminals is also problematic from the point of view of society.

Second, young generations think about drugs and sustainable drug policy lines differently than old generations who have been responsible for deciding the current drug policy (Hakkarainen, Karjalainen \& Salasuo 2020). A majority of young people and young adults personally know people who have used drugs, and many of them have also experimented with cannabis or other drugs themselves. This makes young generations more drug-wise than older generations, meaning that demonizing and narco-phobic images of 'the war on drugs' do not affect them in the same way (Parker, Aldridge \& Measham I998). In the coming years, these young generations will be in leading positions in society. Their appearance is already evident in public discussion.

Third, attitudes among the parents of young people are also changing, especially regarding the risks of experimenting with cannabis. Similarly, their opinions on drug policy may also be changing as they realize the consequences of the present criminal 
control and insufficient availability of treatment services for their offspring.

Fourth, regarding values, principles of fundamental and human rights are becoming more important in society and policy-making. The current calling is for equality and personal integrity instead of control and surveillance. Avoiding stigmatization and promoting equality and uniform rights to treatment and services are also demanded for people with problematic drug use. A question about equality between citizens of different countries might also rise in importance if decriminalization policy, or even more radical reforms like legalization of cannabis, continue to spread globally (Decorte, Lenton \& Wilkins 2020; Eastwood, Fox \& Rosmarin 2016; Unlu, Tammi \& Hakkarainen 2020).

Fifth, different kinds of reforms, like decriminalization in Portugal (Greenwald, 2009; Hughes \& Stevens 2010) and some other countries (Unlu, Tammi \& Hakkarainen 2020); and legal access to medical cannabis and legalization of recreational cannabis in Canada, Uruguay and several US states (Decorte, Lenton \& Wilkins 2020), are followed with great interest among the media and people in Finland. If Norway, as a neighboring Nordic country, will decriminalize all drug use as proposed by the government, it will surely create a lot of attention in Finland, as already mentioned, for example, by some editorials commenting on the first THL blog post. All in all, public discussion and the general drug policy climate in Finland seem to be changing in concert with wider international trends. Consequently, there is now much more room for a rational drug policy debate and different alternatives in public discussion than in previous decades.

Sixth, the present legislation complicates the development of harm reduction measures (Kainulainen 2020). Enabling new measures in the prevention of drug deaths creates a challenge to the current criminal control policy. For example, recently, the City of Helsinki began an initiative to establish a drug consumption room in its area, but no action has been taken since the Criminal Code was seen to be an obstacle (Unlu et al. 202I). The same obstacle was met in a project known from some other countries (e.g. Measham 2019) that would have tested drugs in order to give people who use drugs information about potentially dangerous 
content of the substances. These cases show how local actors who are dealing with drug problems and related harms can - and nowadays will - challenge the national authorities and policy (Blickman \& Sandwell 2020; Jauffret-Roustide \& Cailbault 2018).

Even though it is too early to declare that a change is coming, it is less likely that nothing will change. As previously said, when Finland defined its drug policy line for the first time the emphasis was put almost entirely on criminal control policy. Remarkable changes in the drug situation in the I990s forced the state to counterbalance the criminal control policy with prevention, treatment and harm reduction. In the present context of increasing drug use and related harms, one possible option to develop Finnish drug policy would be to take a further step and put the emphasis clearly on social and health care regarding personal consumption of drugs. This would mean a retreat from the criminalization of drug use. In the redistribution of labour, collaboration between the police and other authorities in preventing drug use would still be important, but the real focus of police work would be redirected towards the markets and drug dealing. At the same time, this would need new investments and efforts in prevention, social and health care, and treatment services from society.

\section{References}

Arponen, A., Brummer-Korvenkontio, H., Liitsola, K., \& Salminen, M. (2008). Trust and free will as the keys to success for the low threshold health service centers (LTHSC). An interdisciplinary evaluation study of the effectiveness of health promotion services for infectious disease prevention and control among injecting drug users. Publications of the National Public Health Institute B24. Helsinki: National Public Health Institute.

Benfer, I., Zahnow, R., Barratt, M., Maier, L., Winstock, \& Ferris, J. (20I 8). The impact of drug policy liberalization on willingness to seek help for problem drug use: A comparison of 20 countries. International Journal of Drug Policy, 56, I62-I75.

Blickman, T., \& Sandwell, C. (2020). City-level policies of regulating recreational cannabis in Europe: From pilot projects to 'local customization'? InT. Decorte, S. Lenton, \& C. Wilkins (Eds.), 
Legalizing cannabis. Experiences, lessons and scenarios (pp. I 80-207). London: Routledge.

Christie, N., \& Bruun, K. (I985). Den gode fienden. Narkotikapolitik $i$ Norden [A suitable enemy - Drug policy in Nordic countries]. Oslo: Universitetsforlaget.

Das, P., \& Horton, R. (2019). The global drug problem: Change but not progression. Lancet 394(IO208): I488-I490.

Decorte, T., Lenton, S., \& Wilkins, C. (Eds.) (2020). Legalizing cannabis. Experiences, lessons and scenarios. London: Routledge.

Eastwood, L. (2020). Cannabis decriminalization policies across the globe. In T. Decorte, S. Lenton, \& C. Wilkins (Eds.), Legalizing cannabis. Experiences, lessons and scenarios (pp. I33-I 53). London: Routledge.

Eastwood, L., Fox, E., \& Rosmarin, A. (2016). A quiet revolution: Drug decriminalization across the globe. 2 nd edition. London: Release Publication.

EMCDDA (2019). European Drug Report 2019. http://www.emcdda .europa.eu/edr2or9_en.

Enzensberger, M. (1989). Tilbaketogets helte. Informations moderne tider, p.3.

Eskola, J., Kilpi, T., Hakkarainen, P., \& Tammi, T. (20I 8). Huumepolitiikka vastaamaan ajan tarpeita [Drug policy should meet the needs of our time]. THL blog post I2.6.20I8, https://blogi.thl.fi/huumepolitiikka-uudistettava-vastaamaan -ajan-tarpeita/.

Greenwald, G. (2009). Drug decriminalization in Portugal: Lessons for creating fair and successful drug policies. Washington, D.C.: Cato Institute.

Gunnar, T., Kankaanpää A., \& Kuoppasalmi, K. (20I9). Wastewater-based empidemiology combined with forensic toxicological information: The approach exemplified by cocaine and metamphetamine use in Finland. A paper presented at the 57th Annual Meeting of the International Association of Forensic Toxicologists (TIAFT), 2-6.9.20I9, Birmingham, UK. http:// www.tiaft2or9.co.uk. 
Hakkarainen, P. (1992). Suomalainen buumekysymys. Huumausaineiden ybteiskunnallinen paikka Suomessa toisen maailman sodan jälkeen [Drug issue after the second wordl war in Finland]. Helsinki: Alkoholitutkimussäätiön julkaisuja 42.

Hakkarainen, P. (I999). Construction of national drug policy in Finland. In J. Derks, A. van Kalmthout, \& H-J. Albrecht (Eds.), Current and future drug policy studies in Europe (pp. 289-302). Freiburg: Max-Planck-Institute.

Hakkarainen, P., \& Karjalainen, K. (20I7). Pilvee, pilvee Kannabiksen käyttötavat, käyttäjät ja poliittiset mielipiteet [Cannabis: use habits, users and public opinion on policy]. Yhteiskuntapolitiikka, 82(I), 19-32.

Hakkarainen, P., \& Tammi, T. (20I8). Huumeiden käytön rangaistavundesta tulisi luopua [We should decriminalize drug use]. THL blog post I3.2.201 8, https://blogi.thl.fi /huumeiden-kayton-rangaistavuudesta-tulisi-luopua/.

Hakkarainen, P., Karjalainen, K., \& Salasuo, M. (2020). Nuoret, entiset nuoret ja huumeet. Miten sukupolvi näkyy huumeiden käytössä ja huumemielipiteissä [Youth and drugs today and yesterday - Are there differences in drug use and opinions?]. Yhteiskuntapolitiikka, 85(5-6), 465-479.

Hakkarainen, P., Tigerstedt, C., \& Tammi, T. (2007). Dual-track drug policy: Normalization of the drug problem in Finland. Drugs: Education, prevention and policy, I4(6), 543-558.

Heinonen, M. (I989). Käyttäjä kohtaa kontrollin. Hoito ja kontrolli buumenuorten kokemina. [Drug user meets control. Experiences of young people of treatment and control]. Helsinki: Sosiaalihallituksen julkaisuja 7 .

Hughes, C., \& Stevens A. (2010). What can we learn from the Portuguese decriminalization of illicit drugs? British Journal of Criminology, 50, 999-1022.

Jauffret-Roustide, M., \& Cailbault, I. (201 8). Drug consumption rooms: Comparing times, spaces and actors in issues of social acceptability in French public debate. International Journal of Drug Policy, 56, 208-2I7. 
Kainulainen H. (2009). Huumeiden käyttäjien rikosoikeudellinen kontrolli. [Criminal Control of Drug Users]. Helsinki: Oikeuspoliittisen tutkimuslaitoksen tutkimuksia 245 .

Kainulainen, H. (2020). Huumeiden käyttäjien rankaisemisesta pitäisi luopua [Drug users should not be punished]. Tiimi, 56(I), 3 (editorial).

Kainulainen, H., Savonen, J., \& Rönkä, S. (Eds.) (20I7). Vanha liitto. Kovien huumeiden käyttäjät I960-I970-lukujen Helsingistä [The old school. Users of hard drugs from the I960s and I970s in Helsinki]. Helsinki: Suomalaisen Kirjallisuuden toimituksia I433.

Kankaanpää, A., Ariniemi, K., Heinonen, M., Kuoppasalmio, K., \& Gunnar, T. (2016). Current trends in Finnish drug abuse: Wastewater based epidemiology combined with other national indicators. Science of the Total Environment, 586, 864-874.

Karjalainen, K., Hakkarainen, P., \& Raitasalo, K. (2019). Nuorten huumeiden käyttö - Tarkastelussa alaikäiset ja täysi-ikäiset nuoret [Drug use among young people - Studying minors and young people over I 8 years]. Yhteiskuntapolitiikka, 84(3), 3 I2-32I.

Karjalainen, K., Hakkarainen, P., \& Salasuo, M. (2019).

Suomalaisten huumeiden käyttö ja buumeasenteet 2018 [Drug use and attitudes towards drugs among Finns in 20I8]. National Institute for Health and Welfare, Statistical Reports 2/20I9, Helsinki.

Karjalainen, K., Pekkanen, N., \& Hakkarainen, P. (2020).

Suomalaisten huumeiden käyttö ja huumeasenteet Hunmeaiheiset väestökyselyt Suomessa I992-20I 8 [Drug use and drug attitudes among Finns - Drug-related population surveys in Finland I992-2018]. National Institute for Health and Welfare, Reports 2/2020, Helsinki.

Kinnunen, A. (2008). Kriminaalipolitiikan paradoksi. Tutkimuksia buumausainerikollisuudesta ja sen kontrollista Suomessa [The paradox of criminal policy. Studies of drug crime and control in Finland]. Oikeuspoliittisen tutkimuslaitoksen julkaisuja 233.

Kontula, A., Aleskerov, T., \& Neuvonen, R. (2020). Tampereen päihdepalvelut päihderiippuvaisten silmin [Drug treatment services 
in Tampere expereinced by the people addicted to alcohol and drugs]. Sosiaaliasema X ry., Tampere.

Measham, F. (2019). Drug safety testing, disposals and dealing in an English field: Exploring the operational and behavioural outcomes of the UK's first onsite 'drug checking' service. International Journal of Drug Policy, 67, 102-107.

NOU 2019:26. Rusreform - fra straff til hjelp [Drug reform - from punishment to help]. Oslo: Norges offentlige utredninger.

Ollgren, J., Forsell, M., Varjonen, V., Alho, H., BrummerKorvenkontio, H., Kainulainen, H., Karjalainen, K., Kotovirta, E., Partanen, A., Rönkä, S., Seppälä, T., \& Virtanen, A. (20I4). Amfetamiinien ja opioidien ongelmakäytön yleisyys Suomessa 2012 [The prevalence of amphetamine and opioid abuse in Finland in 20I2]. Yhteiskuntapolitiikka, 79(5), 498-508.

Olsson, B., Helling, S., Kontula, O., Kristmundson, O., Sindballe, A.-M., \& Skretting, A. (Eds.) (I993). Narkotikasituationen i Nordenutvecklingen 1987-I99I [Use and misuse of narcotic drugs in the Nordic countries - development between I987 and I99I]. Nordiska kontaktmannaorganet för narkotikafrågor, Nordic Council of Ministers, Nord I993:20, Copenhagen.

OSF (20I9). Official Statistics of Finland. Causes of death 2018. Helsinki: Statistics Finland. https://www.stat.fi/til/ksyyt/20 I 8 /ksyyt_20I8_20I9-I2-I6_tie_ooI_fi.html.

Osallistava ja osaava Suomi [Inclusive and competent Finland]. Neuvottelutulos hallitusohjelmasta 3.6.2019. https:// valtioneuvosto.fi/documents/Ior $84 /$ I $3883062 /$ Neuvottelutulos +hallitusohjelmasta+3.6.20I9.pdf/e6od 2023-3596-daee-o5db-d 3 6c96e629fa/Neuvottelutulos+hallitusohjelmasta+3.6.20I9 .pdf? version= $=$.o\&download $=$ true.

Parker, H., Aldridge, J., \& Measham, F. (I998). Illegal leisure - The normalization of adolescent recreational drug use. London: Routledge.

Partanen, J. (2002). Huumeet maailmalla ja Suomessa [Drugs in Finland and worldwide]. In O. Kaukonen, \& P. Hakkarainen (Eds.) Huumeiden käyttäjä hyvinvointivaltiossa [The drug user and the welfare state] (pp. I3-37). Helsinki: Gaudeamus. 
Reuband, K-H. (I998). Drug policies and drug prevalence: The role of demand and supply. European Journal on Criminal Policy, 6(3), $32 \mathrm{I}-336$.

Rönkä, S. (20I 8). Huumeiden käyttäjien kuolemat Suomessa [Drug-related deaths in Finland]. Helsingin yliopisto: Valtiotieteellisen tiedekunnan julkaisuja Io7/201 8.

Rönkä, S., Ollgren, J., Alho, H., Brummer-Korvenkontio, H., Gunnar, T., Karjalainen, K., Partanen, A., \& Väre, T. (2020). Amfetamiinien ja opioidien ongelmakäytön yleisyys Suomessa 2017 [The prevalence of amphetamine and opioid abuse in Finland in 2017]. Duodecim I36 (8), 927-935.

Salasuo, M., Vuori E., Piispa M., \& Hakkarainen P. (2009). Suomalainen buumekuolema 2007 - Poikkitieteellinen tutkimus oikeuslääketieteellisistä kuolinsyyasiakirjoista. [Drug-related deaths in Finland in 2007 - A multidisciplinary study on forensic cause-of-death data.] Helsinki: THL, Reports $43 / 2009$.

Savonen, J., Hakkarainen, P., Kataja, K., Sakki, I., \& Tigerstedt, C. (20I8). Social representations of polydrug use in a Finnish newspaper 1990-2016. Drugs and Alcohol Today, I9 (2), I $23-\mathrm{I} 32$.

Selin, J., Hakkarainen, P., Partanen, A., Tammi, T., \& Tigerstedt, C. (2OI3). From political controversy to a technical problem? Fifteen years of opioid substitution treatment in Finland. International Journal of Drug Policy, 24(6), 66-72.

Stevens, A., Hughes, C., Hulme, S., \& Cassidy, R. (2019).

Depenalisation, diversion and decriminalization: A realist review and programme theory of alternatives to criminalization for simple drug possession. European Journal of Criminology. https:// doi.org/IO.II77/I4773708I98875I4.

Tammi, T. (2007). Medicalising prohibition. Harm Reduction in Finnish and International drug policy. Research reports I6I. Helsinki: Stakes.

Unlu, A., Demiroz, F., Tammi, T., \& Hakkarainen, P. (202I). The complexity of drug consumption room policy and progress in Finland. Contemporary Drug Problems, 48 (2), I 5 I-I 67. 
Unlu, A., Tammi, T., \& Hakkarainen P. (2020). Drug decriminalization policy. Literature review: Models, implementation and outcomes. Finnish institute for health and welfare (THL), Report 9/2020.

Yearbook of Alcohol and Drug Statistics 2019. Official Statistics of Finland, Social Protection. Helsinki: THL. 